This is a version of the accepted manuscript, which is made available for scholarly purposes only, in accordance with the journal's author permissions. The full citation is:

Roberts, K. P., Heaven, S., \& Banks, C. J. (2016). Quantification of methane losses from the acclimatisation of anaerobic digestion to marine salt concentrations. Renewable Energy, 86, 497-506.

http://www.sciencedirect.com/science/article/pii/S0960148115302469

doi:10.1016/j.renene.2015.08.045

\title{
Quantification of methane losses from the acclimatisation of anaerobic digestion to marine salt concentrations
}

Keiron P. Roberts, Sonia Heaven, Charles J. Banks

Faculty of Engineering and the Environment, University of Southampton, Southampton,

SO17 1BJ, UK

(Email K.P.Roberts@soton.ac.uk,S.Heaven@soton.ac.uk, C.J.Banks@soton.ac.uk)

\section{Corresponding author:}

Keiron P. Roberts

Faculty of Engineering and the Environment, University of Southampton, Southampton, SO17 1BJ, UK

\begin{abstract}
The research assessed losses in methane production as a result of raising digester salt concentrations to marine values, and of increasing the feedstock sulphate concentration. Acclimatisation of inoculum from a municipal wastewater biosolids digester was begun by raising the concentration of chloride salts $(\mathrm{Na}, \mathrm{Mg}, \mathrm{Ca}$ and $\mathrm{K})$ to $6-9 \mathrm{~g} \mathrm{~L}^{-1}$, as initial experiments showed higher concentrations caused severe inhibition. After stable operation for four retention times salt content in the reactors and the feed was increased by $1 \mathrm{~g} \mathrm{~L}^{-1}$
\end{abstract}


every 14 days, up to $31.1 \mathrm{~g} \mathrm{~L}^{-1}$. The digesters were fed daily in semi-continuous mode and monitored for performance and stability criteria including specific methane production (SMP). SMP was 6-7\% less than in controls using the same feedstock without saline addition. After steady-state conditions were achieved at high chloride salinity, magnesium chloride was partially replaced by magnesium sulphate to give a range of sulphate concentrations. Higher sulphate concentrations caused initial instability, indicated by volatile fatty acid accumulation. This subsequently reduced and stable operation was achieved at marine sulphate concentrations, but with a $\sim 5 \%$ loss in SMP due to interspecies substrate competition. High sulphate also affected $\mathrm{pH}$, leading to gaseous $\mathrm{H} 2 \mathrm{~S}$ production proportional to the applied sulphate load.

\section{Keywords}

Anaerobic digestion, high salinity, adaptation, inhibition, hydrogen sulphide, methane 


\section{$1 \quad$ Introduction}

If algal biofuels are to become part of the future portfolio of renewable fuel products then cultivation in seawater is probably the only realistic option for very large-scale production (Malcata, 2011). One promising approach is through the production of biomethane by anaerobic digestion (AD) of the whole biomass or of biomass residues after extraction of other products, including bio-oils (Sills et al., 2012; Wiley et al., 2011) Although washing of seaweeds to remove salt before digestion has been normal practice (Sarker et al., 2012), it is not realistic to consider this approach for micro-algae which are harvested at much lower biomass concentrations. Centrifugation and re-suspension in fresh water is technically possible, but is energy intensive and has a high water demand: both factors which are likely to make this approach economically unfeasible. Technologies are therefore needed that can deal with wet feedstocks with a high salt content (Milledge, 2013) and in the case of AD this means developing a process that can operate at seawater concentrations of salt. The earliest study on the effect of the main cations in seawater $(\mathrm{Na}, \mathrm{K}, \mathrm{Ca}$, and $\mathrm{Mg})$ on $\mathrm{AD}$ was that of McCarty et al (1964) in which stimulatory, moderately inhibitory and strongly inhibitory concentrations were reported, all of which were substantially lower than the concentrations found in seawater. These findings have been reiterated in further work (Speece \& Parkin, 1983), and reported tolerances for sodium in non-acclimated mesophilic consortia are generally $<12.0 \mathrm{~g} \mathrm{Na}^{+} \mathrm{L}^{-1}$ for UASB reactors and lower for CSTR operation (Hierholtzer \& Akunna, 2012; Lefebvre et al., 2007). Higher thresholds have been reported, for example of $60 \mathrm{~g} \mathrm{Na} \mathrm{L}^{-1}$ (Aspe et al., 1997); this value, however, was interpolated from the results of batch tests at 20.8 and $120 \mathrm{~g} \mathrm{Na} \mathrm{L}^{-1}$. Oh and Martin (2013) adopted a fundamental thermodynamic approach and applied a stoichiometric model of methanogenesis to predict the inhibition thresholds of sodium. The results show clearly that in thermodynamic terms very high concentrations of sodium can be applied without potential inhibition. Achieving 
this, however, requires overcoming entropic limitations which can result in a loss of spontaneity. The work of Mottet et al., 2014 showed successful methanogenesis using both a halophilic inoculum derived from a saline sediment and an inoculum taken from an industrial wastewater treatment plant with an influent $\mathrm{Na}$ concentration of $10 \mathrm{~g} \mathrm{~L}^{-1}$. Both of these were tested to concentrations of $35 \mathrm{~g} \mathrm{~L}^{-1}$ in batch methanogenic tests, and showed methane conversion efficiencies close to those under non-saline conditions. Non-acclimated biosolids taken from a sewage sludge digester, however, could not acclimatise under the conditions of the batch testing.

When dealing with digestion of marine-derived biomass another potential concern is sulphate, which is the second most abundant anion in seawater with a concentration of around $2.8 \mathrm{~g}$ $\mathrm{SO}_{4} \mathrm{~L}^{-1}$. Sulphur is required in concentrations between $1-25 \mathrm{mg} \mathrm{L}^{-1}$ for the healthy operation of an $\mathrm{AD}$ system, but at higher concentrations its reduction by sulphate-reducing bacteria (SRB) impacts on the digestion process. SRB have a higher growth rate and a lower half saturation value than methanogens (Archer \& Kirsop, 1991), giving them a kinetic advantage in competition for acid intermediate products, and thus reducing the methane production potential of the system (Liamleam \& Annachhatre, 2007). The activities of SRB lead to the formation of reduced sulphur compounds which are present as $\mathrm{H}_{2} \mathrm{~S}$ in the biogas and as both $\mathrm{HS}^{-}$and dissolved $\mathrm{H}_{2} \mathrm{~S}$ in the liquid phase, in proportions depending on the equilibrium conditions. When metal ions are present, these will combine with sulphates to form insoluble metal precipitates. With the exception of these precipitated sulphur compounds, all forms of sulphur can be problematic in digestion and its ancillary processes. In the gaseous form $\mathrm{H}_{2} \mathrm{~S}$ is responsible for malodours and also for corrosion of combustion engines: this means it must be removed from biogas by scrubbing or absorption systems, and all exhaust gases must be treated for odour removal. In soluble form the toxicity of sulphides to methanogens depends on the equilibrium between $\mathrm{HS}^{-}$and soluble $\mathrm{H}_{2} \mathrm{~S}$, which is $\mathrm{pH}$ dependent. Variations in this 
parameter have a major effect on toxicity, as at $\mathrm{pH}>8$ the main component is the less toxic dissociated $\mathrm{HS}^{-}$, whereas at $\mathrm{pH}<7$ soluble $\mathrm{H}_{2} \mathrm{~S}_{\text {liq }}$ is predominant. The latter is much more toxic, as the un-ionized molecule can pass through the cell membrane (Speece \& Parkin, 1983), producing sulphide/disulphide crosslinks between polypeptide chains within the proteins (Koster et al., 1986; Vogels et al., 1988), which in extreme cases result in cell death. The equilibrium between $\mathrm{HS}^{-}$and soluble $\mathrm{H}_{2} \mathrm{~S}$ is also influenced by temperature and salinity (Blunden \& Aneja, 2008; Garrels \& Christ, 1965). As most AD systems work in this $\mathrm{pH}$ range, it is not surprising that a wide range of sulphate concentrations have been reported as either inhibitory or toxic (Koster et al., 1986; Omil et al., 1995; Parkin et al., 1990). The reporting of sulphate toxicity/inhibition/competition values is particularly challenging because of the difficulties in accurate determination of the different forms of reduced sulphur; and for this reason limits are sometimes expressed simply in terms of input sulphate concentration. Threshold values must therefore be treated with caution, but at input sulphate concentrations above $1000 \mathrm{mg} \mathrm{L}^{-1}$ there will generally be a noticeable decrease in methane productivity through competition from $\mathrm{SRB}$, especially if the COD:SO 4 is below 10:1 (Hulshoff Pol et al., 1998; O'Flaherty \& Colleran, 1999; Scherer \& Sahm, 1981). Concentrations of total soluble sulphide between $200-1500 \mathrm{mg} \mathrm{L}^{-1}$ have been reported as inhibitory and/or toxic both to the methanogenic consortium and to SRB, with 50-250 mg L $\mathrm{L}^{-1}$ un-ionized $\mathrm{H}_{2} \mathrm{~S}_{\text {liq }}$ being inhibitory (Koster et al., 1986; Omil et al., 1995; Parkin et al., 1990). Methane productivity may also sometimes be compromised by the precipitation of essential trace metals as insoluble sulphides, thus potentially causing nutrient deficiency and further decreasing the efficiency of the system (Elferink et al., 1994).

Although methanogenesis at sea water concentrations of salt has been demonstrated in batch culture using microalgae and a saline-tolerant inoculum (Mottet et al., 2014), in practice, commercial operation will require supplies of inoculum that are readily available from large- 
scale sources (Hierholtzer \& Akunna, 2012); can be successfully acclimated; and can be maintained under continuous feeding at an acceptable loading

The aim of the current work was therefore firstly to quantify any loss in methane production as a result of the high salinity, and in particular to differentiate clearly between those associated with salinity and those due to sulphate. A secondary objective was to acclimate a methanogenic consortium taken from a municipal sewage sludge digester to high salt concentrations, in preparation for the digestion of a harvested but unwashed marine algal biomass in a subsequent experiment.

\section{$2 \quad$ Materials and methods}

The experimental work was divided into four phases. Phase 1 was a preliminary trial to assess salt dosing strategies and chloride salt mixes for a non-acclimated inoculum. Phase 2 used fresh inoculum that was spiked at different concentrations with a sulphate-free salt mix. Phase 3 used the acclimated inoculum from phase 2 and subjected it to increasing concentrations of chloride salts. Phase 4 assessed the effect of replacing a proportion of magnesium chloride with magnesium sulphate to give a range of sulphate concentrations.

The work in phases 1-3 was carried out in 10 fed-batch continuously-stirred tank reactor (CSTR) digesters each with a working volume of $1.5 \mathrm{~L}$, while phase 4 used eight fed-batch shake flasks each of $400 \mathrm{~mL}$ working volume.

\section{$2.1 \quad$ Feedstock}

In phase 1-3 of the work, each digester was fed daily on a combined feed consisting of $90 \mathrm{~mL}$ of a base synthetic medium (BSM) with the composition shown in Table 1, and $10 \mathrm{ml}$ of a saline solution made up of concentrated salt solution and de-ionized (DI) water. The 
concentrated salt solution contained $\left(\mathrm{g} \mathrm{L}^{-1}\right) 27.4 \mathrm{NaCl}, 3.2 \mathrm{MgCl}_{2} \cdot 6 \mathrm{H}_{2} \mathrm{O}, 1.51 \mathrm{CaCl}_{2}$ and 0.7 $\mathrm{KCl}$ to give molar ratios of 1:0.87:0.03:0.03:0.02 for $\mathrm{Cl}, \mathrm{Na}, \mathrm{Mg}, \mathrm{Ca}$ and $\mathrm{K}$, similar to mean ocean ratios (Brown et al., 2005). This concentrate was diluted as required to give the desired additional salt concentration in the combined feed. In addition, in phase 1 one pair of reactors was run on BSM supplemented with a commercially available sea salt preparation (Ultramarine Synthetic Sea Salt, Bristol, UK).

In phase 4 of the work, the concentrated salt stock solution was made up of $\left(\mathrm{g} \mathrm{L}^{-1}\right) 27.4 \mathrm{NaCl}$, 1.51 $\mathrm{CaCl}_{2}, 0.7 \mathrm{KCl}$ and mixtures of $\mathrm{MgCl}_{2}$ and $\mathrm{MgSO}_{4}$ in the proportions required to give sulphate concentrations of $0,0.16,0.79,1.58,2.36,3.15,3.94$ and $4.73 \mathrm{~g} \mathrm{SO}_{4} \mathrm{~L}^{-1}$.

\subsection{Laboratory-scale reactors}

The CSTRs used in phase 1-3 of the work were constructed from PVC. The top plate had a gas collection outlet, an access port sealed with a rubber bung, and a draught tube liquid seal providing access for an asymmetric bar stirrer driven by a $40 \mathrm{rpm}$ motor. Digester temperature was maintained at $35 \pm 0.5^{\circ} \mathrm{C}$ by circulating water from a thermostaticallycontrolled reservoir through copper heating coils wrapped around each reactor. Feedstock addition and digestate removal were carried out via the access port, the latter by means of a $100 \mathrm{~mL}$ syringe. Gas production was measured continuously by tipping-bucket gas counters (Walker et al., 2009), which could be connected to gas-impermeable sampling bags. Gas counter calibration was checked regularly by measuring the volume of gas collected using a water displacement weight-type gasometer (Walker et al., 2009). All gas volumes reported are corrected to standard temperature and pressure (STP) of $0{ }^{\circ} \mathrm{C}$ and $101.325 \mathrm{kPa}$.

Phase 4 used eight $500 \mathrm{~mL}$ Erlenmeyer flasks each fitted with a rubber bung with two tube insertions: one for collection of gas in a gas bag and the other, which was normally closed, 
for feed addition and digestate removal. The flasks were maintained in an orbital incubator (Orbi-Safe, Gallenkamp) at $35 \pm 0.5^{\circ} \mathrm{C}$ and $120 \mathrm{rpm}$, and the volume of gas collected was measured daily as above.

\subsection{Inoculum}

Inoculum used in phase 1 and phase 2 was taken from a mesophilic anaerobic digester treating municipal wastewater biosolids at Millbrook wastewater treatment plant, Southampton, UK. The inoculum in phase 3 was taken from phase 2, and that for phase 4 from phase 3 .

\subsection{Experimental design}

The digesters used in phases 1-3 were numbered R1-10 and operated in duplicate pairs. In phase 1 the inoculum in R5-6 was adjusted (spiked) on day 13 to a salt concentration of $10 \mathrm{~g}$ $\mathrm{L}^{-1}$ and from then on these digesters were fed with BSM made up to a $10 \%$ concentration of mixed chloride salts. In R1-4 and R7-8 there was no spiking of the inoculum, and salt was introduced as part of the daily feed at the concentrations shown in Table 2. R1-4 received dilutions of the stock mixed chloride salts, and R7-8 the commercial sea salt mix. Digesters R9-10 were maintained as controls fed on BSM and DI water without any salt addition. In phase 2 the inoculum in each reactor was initially adjusted to the target salt concentration (Table 2), and the reactor was then fed on BSM made up with salt solution to the target concentration. In phase 3 the salt concentration in the reactors and in the feed was further increased by $1 \mathrm{~g} \mathrm{~L}^{-1}$ every 14 days up to day 350 . The concentration was then raised to $31.1 \mathrm{~g}$ $\mathrm{L}^{-1}$ and maintained at this concentration until day 400. In all cases the hydraulic retention time (HRT) was 15 days. 
Inoculum for Phase 4 was prepared by mixing the digestate from the salt-supplemented digesters R1-8 at the end of phase 3. $400 \mathrm{ml}$ of inoculum was added to each Erlenmeyer flask and the sulphate concentration was adjusted using $\mathrm{MgSO}_{4}$ to give initial concentrations as shown in Table 2 . The flasks were then fed at same HRT and OLR as previously applied to the CSTR digesters, the only difference being the adjustment of the sulphate concentration in the salt mix added to the BSM.

\subsection{Analytical methods}

Biogas composition was determined using a Varian CP-3400 gas chromatograph (GC) calibrated with a 60:40\% $\mathrm{CH}_{4}: \mathrm{CO}_{2}$ (v/v) standard gas (BOC Ltd, UK). $\mathrm{pH}$ was determined using a Mettler Toledo FE20/EL20 pH meter with a combination glass electrode calibrated in buffers at pH 7.0 and 9.2 (Fisher Scientific, UK). Alkalinity was determined by titration with a $0.25 \mathrm{~N} \mathrm{H}_{2} \mathrm{SO}_{4}$ solution to endpoints of 5.7 and 4.3 to allow determination of total (TA), partial (PA) and intermediate alkalinity (IA) (Ripley et al., 1986). Total Kjeldahl Nitrogen (TKN) and Total Ammonia Nitrogen (TAN) were determined using a Kjeltech digestion block and a Büchi steam distillation unit, according to the manufacturers' instructions. Volatile fatty acid (VFA) concentrations were measured using a Shimadzu 2010 GC. Elemental composition (C, H, N and S) content was determined using a FlashEA 1112 Elemental Analyzer (Thermo Finnigan, Italy), with methionine, 1-cystine, pasta, basil leaf and sulphanilamide as standards and vanadium pentoxide added as a catalyst for sulphur determination. $\mathrm{H}_{2} \mathrm{~S}$ gas was analysed using a $\mathrm{H}_{2} \mathrm{~S}-\mathrm{AE}$ sensor (Alphasense Ltd, UK) at a flow of $500 \mathrm{~mL} \mathrm{~min}^{-1}$. The sensor was calibrated with a gas mixture containing $404 \mathrm{ppm}_{2} \mathrm{~S}$, $35.19 \% \mathrm{CO}_{2}$, and the balance $\mathrm{CH}_{4}$ (SIP Analytical Ltd, UK). 
Theoretical methane potential (TMP) was calculated from the Buswell equation (Symons \& Buswell, 1933), with elemental composition data taken from direct measurement of $\mathrm{C}, \mathrm{H}$ and $\mathrm{N}$, and $\mathrm{O}$ obtained by difference, on a \%VS basis. The theoretical calorific value (TCV) of the feed was calculated according to the Dulong equation (IFRF, 2014). The higher heat value of $\mathrm{CH}_{4}$ was taken as $39.84 \mathrm{MJ} \mathrm{m}^{-3}$ at $\mathrm{STP}$. VS destruction was calculated based on the percentage VS concentrations in feed and digestate, without taking into account any changes in the respective volumes. Soluble $\mathrm{H}_{2} \mathrm{~S}$ was calculated using Henry's Law based on the measured headspace $\mathrm{H}_{2} \mathrm{~S}$ concentration. The un-ionized fraction of $\mathrm{H}_{2} \mathrm{~S}$ was determined according to Millero (1986) and Sigel et al. (1991), with the total soluble sulphide fraction presumed to consist of $\mathrm{H}_{2} \mathrm{~S}$ and $\mathrm{HS}^{-}$due to the operational $\mathrm{pH}$ range within the digesters.

\section{$3 \quad$ Results and discussion}

\subsection{BSM feed}

Measured values for key properties of the BSM are shown in Table 3. Based on these results the maximum TMP according to the Buswell equation was $0.452 \mathrm{~L} \mathrm{CH}_{4} \mathrm{~g}^{-1}$ VS added, and the TCV was around 20.0 $\mathrm{MJ} \mathrm{kg}^{-1} \mathrm{VS}$. The average organic loading rate (OLR) on the reactors was $2.1 \pm 0.1 \mathrm{~g} \mathrm{VS} \mathrm{L}^{-1}$ day $^{-1}$.

\subsection{Phase 1 - preliminary trial}

Specific methane production (SMP) and volumetric biogas production (VBP) in R5\&6 supplemented to $10 \mathrm{~g} \mathrm{~L}^{-1}$ of salt fell as soon as the digesters were spiked to the target concentration (Figure 1a and b), and continued to decline steadily. VBP, SMP and biogas methane content in digesters $\mathrm{R} 3 \& 4$ with feed-only supplementation to $16 \mathrm{~g} \mathrm{~L}^{-1}$ began to fall from day 23, and declined even more rapidly. The start of this decline in biogas production corresponded to an estimated dilute-in salt concentration of $9 \mathrm{~g} \mathrm{~L}^{-1}$. These changes were 
accompanied by a steady fall in $\mathrm{pH}$ and a rise in VFA concentrations (Figure 1c and d); and on day 35 feeding of digesters R3-6 was stopped. In the following days there was little or no recovery in biogas production or $\mathrm{pH}$. Gas production and other parameters in digesters $\mathrm{R} 1 \& 2$ and $\mathrm{R} 7 \& 8$ supplemented at $8 \mathrm{~g} \mathrm{~L}^{-1}$ was similar to that in the controls, with no obvious difference between the laboratory and commercial sea salt. There was a small increase in VFA concentration in these digesters from around day 30: the reasons for this are not known, but similar transient VFA peaks of this type have previously been observed when inoculum from this source is acclimated to a new feedstock (unpublished data, University of Southampton). Based on these results, it was concluded that the inoculum was unable to adapt to shock salt additions of $\geq 10 \mathrm{~g} \mathrm{~L}^{-1}$ and it was therefore decided to test a range of initial salt additions from 6-9 $\mathrm{g} \mathrm{L}^{-1}$ in phase 2 of the work.

\subsection{Phase 2 - initial acclimatisation to $\mathrm{Cl}, \mathrm{Na}, \mathrm{Mg}$, $\mathrm{Ca}$, and $\mathrm{K}$}

All of the digesters acclimated successfully to the feedstock and the initial salt additions applied in this phase of the work, with only minor signs of stress or instability. TAN rose in response to the feedstock composition, but stabilised rapidly at around $2.4 \mathrm{~g} \mathrm{~N} \mathrm{~L}^{-1}$ (Figure 2a). $\mathrm{pH}$ rose from 7.3 to around 8 in all digesters by day 30 , then fell back to 7.5-7.7 (Figure $2 \mathrm{~b}$ ). Total alkalinity increased, reflecting the increase in TAN content, then stabilised at around $7.4 \mathrm{~g} \mathrm{CaCO}_{3} \mathrm{~L}^{-1}$ (Figure 2c). Digesters R3-R8 with salt supplementation above $6 \mathrm{~g} \mathrm{~L}^{-1}$ showed transient VFA peaks between day 30-60 (Figure 2d), reaching as high as $4.8 \mathrm{~g} \mathrm{~L}^{-1}$ in R4. The VFA peaks were reflected in the partial alkalinity and in the IA/PA ratio (Figure 2e and f); by the end of Phase 2, however, these were again close to the control values in R9\&10. Digestate solids contents (Figure $2 \mathrm{~g}$ and $\mathrm{h}$ ) reflected both acclimatisation to the feedstock and the amount of salt addition in each pair of digesters, with TS contents rising in response to the initial salt addition, then declining. A mass balance approach and visual observation at the 
end of the run indicated this may have been due to precipitation of struvite on solid surfaces in the digester. Gas production in the salt-supplemented digesters was similar to that in the controls (Figure $2 \mathrm{i}$ and $\mathrm{j}$ ), with exception of R8 which showed a temporary drop of around $20 \%$ between days 3-34: the reason for this is unknown, but performance subsequently recovered to match that in the other digesters. The high SMP in R3\&4 at the end of phase 1 reflects the decline in accumulated VFA (Figure $2 \mathrm{j}$ and $\mathrm{d}$ ). Table 4 shows the average values of key monitoring parameters for the last 20 days of Phase 2, after 3 HRT at the additional salt doses used.

At the end of Phase 2 average volumetric biogas production (VBP) and specific methane production (SMP) in all digesters apart from R7 appeared to show a slight downward trend with increasing salt addition (Table 4). The controls R9\&10 achieved 92\% of the TMP and conversion of $83 \%$ of the TCV into $\mathrm{CH}_{4}$. The SMP of digesters $\mathrm{R} 1 \& 2$ supplemented at $6 \mathrm{~g} \mathrm{~L}^{-}$

${ }^{1}$ was equal to that of the controls, while $\mathrm{R} 8$ with $9 \mathrm{~g} \mathrm{~L}^{-1}$ salt addition achieved $83 \%$ of the TMP and $76 \%$ conversion of TCV. These results indicated that after $>3 \mathrm{HRT}$ of operation at their respective salinities there were still some small differences in performance between the controls and the more heavily salt-supplemented digesters, but that the anaerobic consortium could successfully adapt to an initial step in salinity to $9 \mathrm{~g} \mathrm{~L}^{-1}$.

\subsection{Phase 3 - increase in salt addition}

In Phase 3 the added salt concentration in the salt-supplemented digesters and in the feed was increased by $1 \mathrm{~g} \mathrm{~L}^{-1}$ every 14 days. With each step in salinity a small decrease in $\mathrm{pH}$ and SMP was observed compared to the controls, followed by a recovery in SMP and a partial recovery in $\mathrm{pH}$. The $\mathrm{pH}$ in the supplemented digesters fell to around 7.4-7.5 by day 100 and continued to decline to around 7.3-7.4 by day 350 (Figure 3a). There was some disturbance in 
TAN concentrations after salt incrementation began (Figure 3b), perhaps indicating changes in the concentration of microbial biomass present in the reactor (Lindorfer et al., 2012). TA and PA in the salt-supplemented digesters fell from around day 200 (Figure $3 \mathrm{c}$ and d), corresponding to salt concentrations of $16-19 \mathrm{~g} \mathrm{~L}^{-1}$. The fall was especially sharp in R1\&2, where PA dropped to 2.1 and $2.5 \mathrm{~g} \mathrm{CaCO}_{3} \mathrm{~L}^{-1}$ over the next 60 days, with an IA/PA ratio above 1 (Figure 3e). VFA peaks of around $5 \mathrm{~g} \mathrm{~L}^{-1}$ appeared in both digesters in this period (Figure 3f), consisting primarily of acetic acid but also $1.0-1.3 \mathrm{~g} \mathrm{~L}^{-1}$ of propionic, $0.7 \mathrm{~g} \mathrm{~L}^{-1}$ iso-valeric and small increases in butyric, iso-butyric and valeric acids (Figure $3 \mathrm{~g}$ and $\mathrm{h}$ ). VFA concentrations fell rapidly after day 274 , reaching values below $0.1 \mathrm{~g} \mathrm{~L}^{-1}$ by day 281 . Similar but much smaller VFA peaks were observed in the digesters at higher salt loadings, with the magnitude corresponding inversely to added salt concentration. In R1\&2 there were accompanying falls in $\mathrm{pH}, \mathrm{VBP}, \mathrm{SMP}$ and biogas methane content (Figure $3 \mathrm{i}$ and $\mathrm{j}$ ), which then recovered to at or near their previous values by day 270. No significant changes occurred in the other salt-supplemented digesters. After day 350 when the added salt concentration was equalised in all of the supplemented digesters, transient VFA peaks were seen in the digesters that had previously been at slightly lower loadings, but these had disappeared by day 400 .

Table 5 shows the average values of key monitoring parameters for the last 20 days of Phase 3. The $\mathrm{pH}$ in the salt-supplemented digesters was lower than in the controls, with average values of 7.33 and 7.67 respectively. TAN concentrations were also slightly lower on average. The IA/PA ratio of the salt-supplemented digesters was slightly higher than in the controls, at 0.37 and 0.26 respectively, although both were within the range considered as indicating stability. The average VBP and SMP of the salt-supplemented reactors was lower than that of the controls, although R1 and especially R5 showed good gas production. This difference was 
supported by the slightly higher VS content in the salt-supplemented digesters compared to the controls, corresponding to average VS destructions of 70 and $79 \%$ respectively.

By the end of Phase 2 all digesters appeared to be operating stably in terms of $\mathrm{pH}$, alkalinity and gas production (Figure 3). The salt-supplemented digesters on average showed a 6-7\% reduction in SMP and percentage conversion of TCV compared to the controls.

\subsection{Phase 4 - sulphate addition}

The main monitoring parameters for phase 4 are shown in Figure 4. The control reactor F1 showed a small rise in VFA concentration and IA/PA ratio, possibly due to disturbances during the transfer of the inoculum from phase 3; but no longer-term changes were seen and gas production and other parameters maintained their previous values, with $\mathrm{pH}$ averaging around 7.5.

Reactors F2 and F3 with the lowest concentrations of added sulphate showed little or no effect from the sulphate supplementation: the $\mathrm{pH}$ remained steady at an average value of 7.5 (Figure 4a), while TA and IA/PA stabilised at average values of 4.8 and $5.0 \mathrm{~g} \mathrm{CaCO}_{3} \mathrm{~L}^{-1}$ and 0.34 and 0.35 , respectively (Figure $4 \mathrm{~b}$ and c). VFA concentrations remained below $0.2 \mathrm{~g} \mathrm{~L}^{-1}$ (Figure $4 \mathrm{~d}$ ), and gas production (Figure $4 \mathrm{e}$ and $\mathrm{f}$ ) and biogas methane content were similar to

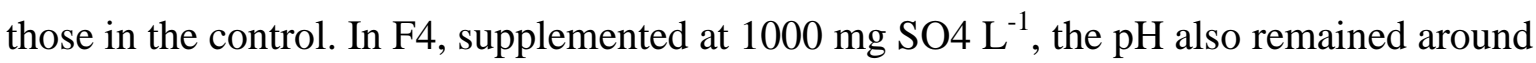
7.5 and TA stabilised at $5.3 \mathrm{~g} \mathrm{CaCO}_{3} \mathrm{~L}^{-1}$, with an IA/PA ratio of 0.36 . In this reactor, however, the VFA concentration rose to $2.5-2.7 \mathrm{~g} \mathrm{~L}^{-1}$ between days $14-28$, then declined to the same range as in the control (Figure 4d). Gas production in F4 was slightly below that in the control in this period but recovered by around day 70 . 
Reactors F5-8 with increasing sulphate concentrations showed more marked reactions to the sulphate addition. Between day 0-50 the $\mathrm{pH}$ fell to 7.1 in F5 and to 7.2 in F6 and 7 (Figure 4a), before gradually returning to around 7.5 by the end of the run. VFA rose rapidly until day 14 and remained high until day 68, before declining towards control values. Average VFA concentrations during this period were in reverse order of added sulphate concentration, at around 5.9, 5.0, 4.3 and $2.5 \mathrm{~g} \mathrm{~L}^{-1}$ in F5, 6, 7 and 8 respectively (Figure 4d). The main component in each case was acetic acid, with iso-valeric acid present in concentrations of up to $1 \mathrm{~g} \mathrm{~L}^{-1}$ and small amounts of iso-butyric acid. The effect of the VFA was reflected in the IA/PA ratios for each reactor (Figure 4c). TA in F5-7 stabilised from day 126 on at 6.2-6.5 $\mathrm{g}$ $\mathrm{CaCO}_{3} \mathrm{~L}^{-1}$, while in $\mathrm{F} 8$ the average TA was much higher at $7.6 \mathrm{~g} \mathrm{CaCO}_{3} \mathrm{~L}^{-1}$ (Figure $4 \mathrm{~b}$ ). IA/PA ratios for F5-7 fell as the VFA accumulation declined, but were still 0.5 or above by the end of the run, while the IA/PA ratio in F8 was below 0.4 from day 100 on (Figure 4c).

These differences between the more heavily sulphate-loaded reactors were also evident in the gas production, with VBP in F5-7 falling to half that of the controls by around day 50, accompanied by a drop of $8-10 \%$ in biogas methane content and corresponding decreases in SMP (Figure 4e and f). Gas production in these reactors then gradually recovered, although it was still only $85-90 \%$ of the control value at the end of the run. In contrast gas production in F8 was only slightly reduced up to day 38 and had recovered to the control value by day $\sim 120$. The lower gas production in F5 was reflected in a fall in VS destruction, to around $32 \%$ on day 55 (Figure 4g). By the end of the run VS destruction in F1-4 and F8 had stabilised at between 65-69\%, while F5-7 still showed reduced values ranging from 53-63\%.

TAN concentrations in all reactors were similar, averaging around $2.5 \mathrm{~g} \mathrm{~N} \mathrm{~L}^{-1}$, with the exception of F7 (2500 $\mathrm{mg} \mathrm{SO}_{4} \mathrm{~L}^{-1}$ ) which stabilised at $2.2 \mathrm{~g} \mathrm{~N} \mathrm{~L}^{-1}$ (Figure $4 \mathrm{~h}$ ). 
Figure $5 \mathrm{a}$ and $\mathrm{b}$ show the biogas $\mathrm{H}_{2} \mathrm{~S}$ concentration and volumetric $\mathrm{H}_{2} \mathrm{~S}$ production during the experimental period. Initially $\mathrm{H}_{2} \mathrm{~S}$ production was non-linear in relation to sulphate addition, with reactors F2-4 at lower sulphate concentrations producing proportionally more $\mathrm{H}_{2} \mathrm{~S}$ than F5-8 at intermediate and higher sulphate concentrations: results for day 4 are shown in Figure 5c. After $2 \mathrm{HRT}$, the relationship between both concentration and volume of $\mathrm{H}_{2} \mathrm{~S}$ produced with the amount of added sulphate had stabilised and become more linear (Figure 5d) suggesting that the system had adapted.

These patterns in $\mathrm{H}_{2} \mathrm{~S}$ production may also help to indicate the reasons for the behaviour of the different reactors. $\mathrm{H}_{2} \mathrm{~S}$ is produced by sulphate-reducing bacteria (SRB), and in the process of sulphate reduction hydrogen ions are consumed, thus increasing the alkalinity and providing additional buffering. The initial addition of sulphate caused rapid production of $\mathrm{H}_{2} \mathrm{~S}$ and an increase in soluble sulphide concentrations to $1200 \mathrm{mg} \mathrm{L}^{-1}$ or more, within reported values for the toxicity threshold of 200-1500 $\mathrm{mg} \mathrm{L}^{-1}$ (Chen et al., 2008; Koster et al., 1986; Parkin et al., 1990). This resulted in partial inhibition of methanogenesis, leading to the observed rise in VFA concentrations in reactors with sulphate additions $\geq 1.58 \mathrm{~g} \mathrm{SO}_{4} \mathrm{~L}^{-1}$. At $1.58 \mathrm{~g} \mathrm{SO}_{4} \mathrm{~L}^{-1}$ (F4) $\mathrm{pH}$ remained stable and the VFA accumulation was consumed fairly rapidly. At 236, 3.15 and $3.94 \mathrm{~g} \mathrm{SO}_{4} \mathrm{~L}^{-1}$ (F5-7) the VFA increase led to a fall in $\mathrm{pH}$, whereas at $4.73 \mathrm{~g} \mathrm{SO} 4 \mathrm{~L}-1$ (F8) the $\mathrm{pH}$ increased slightly.

As noted earlier, $\mathrm{pH}$ is a major controlling factor in relation to sulphide speciation and a reduction can shift the equilibrium between $\mathrm{HS}^{-}$and the more toxic $\mathrm{H}_{2} \mathrm{~S}$, potentially causing inhibition of methanogenesis. Reactors F5-7 with intermediate sulphate addition had lower initial conversion of $\mathrm{H}_{2} \mathrm{~S}$, less consumption of $\mathrm{H}^{+}$and therefore lower partial alkalinity and 
greater $\mathrm{pH}$ change. In contrast in $\mathrm{F} 8$, the reactor with the highest sulphate conversion, the consumption of $\mathrm{H}^{+}$was sufficient to buffer $\mathrm{pH}$ change and reduce VFA formation. $\mathrm{pH}$ values in F5-7 were in the critical range for sulphide toxicity: in F6 and F7 the minimum pH was around 7.2, where $88 \%$ of sulphide is present as $\mathrm{HS}^{-}$; whereas in $\mathrm{F} 5$ at a minimum $\mathrm{pH}$ of 7.1 the fraction of $\mathrm{H}_{2} \mathrm{~S}$ increases to $19 \%$. Parkin et al. (1990) reported inhibitory sulphide concentrations in the range of $100-800 \mathrm{mg} \mathrm{L}^{-1}$ dissolved sulphide or approximately $50-400$ $\mathrm{mg} \mathrm{L}^{-1}$ undissociated H2S. O'Flaherty et al. (1998) observed that sulphide inhibition for both $\mathrm{SRB}$ and methanogens was related to the un-ionized sulphide concentration in the $\mathrm{pH}$ range 6.8-7.2 and to total sulphide concentrations above $\mathrm{pH}$ 7.2. The apparent fall in VS destruction observed in F5 during the period of low $\mathrm{pH}$ may also indicate some sulphide inhibition of hydrolytic and acidogenic organisms, in addition to methanogenesis.

As $\mathrm{H}_{2} \mathrm{~S}$ production in the reactors with intermediate sulphate addition stabilised after $2 \mathrm{HRT}$, the alkalinity and $\mathrm{pH}$ recovered, allowing the VFA accumulation to be reduced. By the end of the experimental period gas production in F2, 3 and 8 was equal to that in the control while that in digesters F5-7 was approaching the control value. Figure 5d shows the relationship between sulphate addition, volumetric $\mathrm{H}_{2} \mathrm{~S}$ production and substrate $\mathrm{COD} / \mathrm{SO}_{4}$ ratio: it can be seen that the reactors were successfully able to convert the maximum marine sulphate concentration at the $\mathrm{COD}: \mathrm{SO}_{4}$ ratios applied.

Final sulphate concentrations in the digestate ranged from $16-257 \mathrm{mg} \mathrm{SO}_{4} \mathrm{~L}^{-1}$, corresponding to conversion of $94-95 \%$ of the added sulphate in reactors $\mathrm{F} 3-8\left(500-3000 \mathrm{mg} \mathrm{SO}_{4} \mathrm{~L}^{-1}\right)$, and of $84 \%$ for $\mathrm{F} 2\left(100 \mathrm{mg} \mathrm{SO}_{4} \mathrm{~L}^{-1}\right)$. These values are similar to the conversion efficiencies of 90-96\% reported by (Omil et al., 1995). 


\section{Conclusions}

The results demonstrated the feasibility of acclimating digestate from a mesophilic digester treating municipal wastewater biosolids, a readily-available and high-volume inoculum source, to a high salinity feedstock. Before acclimatisation the digestate had a salt tolerance of $<10 \mathrm{~g} \mathrm{~L}^{-1}$ but by gradual incremental addition under continuous feeding conditions stable operation was achieved at a chloride salt concentration of $31.1 \mathrm{~g} \mathrm{~L}^{-1}$. Longer term operation in steady state conditions allowed quantification of the SMP which was 6-7\% lower in the saline digesters than the non-saline control; no other detrimental effects were evident. On substituting a proportion of the chloride salts with sulphate there was little or no impact at concentrations $<1000 \mathrm{mg} \mathrm{L}^{-1}$. At higher concentrations there were initial transient changes, with the reactors showing some VFA accumulation in proportion to the sulphate dose applied. This in turn led to a decrease in VBP and a drop in the biogas methane content. These effects could be attributed to toxicity from $\mathrm{H}_{2} \mathrm{~S}$, and the extent to which this occurred in each case was accounted for by $\mathrm{pH}$ changes that affect the chemical equilibrium of the reduced sulphur species. After a period of acclimatisation the digesters receiving marine or higher concentrations of sulphate adapted, with $94-95 \%$ of the added sulphate being reduced to sulphide. This led to a reduction in SMP which was $\sim 5 \%$ lower than in non-salt supplemented controls; in other respects digester performance and stability were comparable. The results thus provide an insight into the relative effect of chlorides and sulphates in digestion of saline feedstocks, and confirm the potential for commercial-scale AD of marine algal biomass without the need for a washing step.

\section{Acknowledgements}


Thanks are due to the UK Engineering and Physical Sciences Research Council (PhD

scholarship), the EU FP7 ALL-GAS project (268208) and the EU FP7 ECOFUEL project

(246772) for supporting this research.

\section{References}

Archer, D.B., Kirsop, B.H. 1991. The microbiology and control of anaerobic digestion. . in: Anaerobic digestion: a waste treatment technology, (Ed.) A. Wheatley, pp. 43.

Aspe, E., Marti, M.C., Roeckel, M. 1997. Anaerobic treatment of fishery wastewater using a marine sediment inoculum. Water Research, 31(9), 2147-2160.

Blunden, J., Aneja, V.P. 2008. Characterizing ammonia and hydrogen sulfide emissions from a swine waste treatment lagoon in North Carolina. Atmospheric Environment, 42(14), 3277-3290.

Brown, E., Colling, A., James, R., Park, D., Phillips, J., Rothery, D., Wright, J. 2005. Marine Biogeochemical Cycles. 2 ed. Elsevier, Oxford.

Chen, Y., Cheng, J.J., Creamer, K.S. 2008. Inhibition of anaerobic digestion process: A review. Bioresource Technology, 99(10), 4044-4064.

Elferink, O.S., Visser, A., Hulshoff Pol, L.W., Stams, A.J.M. 1994. Sulfate reduction in methanogenic bioreactors. FEMS Microbiology Reviews, 15(2-3), 119-136.

Garrels, R., Christ, C. 1965. Solutions, Minerals and Equilibria, Harper and Row. New York.

Hierholtzer, A., Akunna, J.C. 2012. Modelling sodium inhibition on the anaerobic digestion process. Water Science \& Technology, 66(7), 1565-1573.

Hulshoff Pol, L., Lens, P.L., Stams, A.M., Lettinga, G. 1998. Anaerobic treatment of sulphate-rich wastewaters. Biodegradation, 9(3-4), 213-224.

Idrus, S., Banks, C., Heaven, S. 2012. Assessment of the potential for biogas production from wheat straw leachate in upflow anaerobic sludge blanket digesters. Water Science \& Technology, 66(12), 2737-2744.

IFRF. 2014. Online Combustion Handbook (Method from Combustion File 24), International Flame Research Foundation, pp. 1607-9116.

Koster, I.W., Rinzema, A., de Vegt, A.L., Lettinga, G. 1986. Sulfide inhibition of the methanogenic activity of granular sludge at various pH-levels. Water Research, 20(12), 1561-1567.

Lefebvre, O., Quentin, S., Torrijos, M., Godon, J.J., Delgenès, J.P., Moletta, R. 2007. Impact of increasing $\mathrm{NaCl}$ concentrations on the performance and community composition of two anaerobic reactors. Applied Microbiology and Biotechnology, 75(1), 61-69.

Liamleam, W., Annachhatre, A.P. 2007. Electron donors for biological sulfate reduction. Biotechnology Advances, 25(5), 452-463.

Lindorfer, H., Ramhold, D., Frauz, B. 2012. Nutrient and trace element supply in anaerobic digestion plants and effect of trace element application. Water Science and Technology, 66(9), 1923-1929.

Malcata, F.X. 2011. Microalgae and biofuels: A promising partnership? Trends in Biotechnology, 29(11), 542-549.

McCarty, P.L. 1964. Anaerobic waste treatment fundamentals, Public Works 95 (9) 107-112.

Milledge, J. 2013. Energy balance and techno-economic assessment of algal biofuel production systems, University of Southampton. 
Millero, F.J. 1986. The thermodynamics and kinetics of the hydrogen sulfide system in natural waters. Marine Chemistry, 18(2-4), 121-147.

Mottet, A., Habouzit, F., Steyer, J.P. (2014) Anaerobic digestion of marine microalgae in different salinity levels, Bioresour. Technol. 158 300-306.

O'Flaherty, V., Colleran, E. 1999. Effect of sulphate addition on volatile fatty acid and ethanol degradation in an anaerobic hybrid reactor. I: process disturbance and remediation. Bioresource Technology, 68(2), 101-107.

O'Flaherty, V., Mahony, T., O'Kennedy, R., Colleran, E. 1998. Effect of pH on growth kinetics and sulphide toxicity thresholds of a range of methanogenic, syntrophic and sulphate-reducing bacteria. Process Biochemistry, 33(5), 555-569.

Oh, S.T., Martin, A.D. (2013) A thermodynamic equilibrium consideration of the effect of sodium ion in acetoclastic methanogenesis, J. Chem. Technol. Biotechnol. 88, (5) 834-844.

Omil, F., Mendez, R., Lema, J.M. 1995. Anaerobic treatment of saline wastewaters under high sulphide and ammonia content. Bioresource Technology, 54(3), 269-278.

Parkin, G.F., Lynch, N.A., Kuo, W.C., Vankeuren, E.L., Bhattacharya, S.K. 1990. Interaction between sulfate reducers and methanogens fed acetate and propionate. Research Journal of the Water Pollution Control Federation, 62(6), 780-788.

Ripley, L.E., Boyle, W.C., Converse, J.C. 1986. Improved alkalimetric monitoring for anaerobic-digestion of high strength wastes. J. Water Pollution, 58(5), 406-411.

Sarker, S., Bruhn, A., Ward, A.J., Møller, H.B. 2012. Bio-fuel from anaerobic co-digestion of the macro-algae Ulva lactuca and Laminaria digitata. Renewable energy and energy efficiency. In: Proceedings of the International Scientific Conference. Jelgava, Latvia. pp. 28-30.

Scherer, P., Sahm, H. 1981. Influence of sulphur-containing compounds on the growth of Methanosarcina barkeri in a defined medium. European journal of applied microbiology and biotechnology, 12(1), 28-35.

Sigel, H., Zuberbuhler, A.D., Yamauchi, O. 1991. Comments on potentiometric pH titrations and the relationship between $\mathrm{pH}$-meter reading and hydrogen-ion concentration. Analytica Chimica Acta, 255(1), 63-72.

Sills, D.L., Paramita, V., Franke, M.J., Johnson, M.C., Akabas, T.M., Greene, C.H., Tester, J.W. 2012. Quantitative uncertainty analysis of life cycle assessment for algal biofuel production. Environmental science \& technology, 47(2), 687-694.

Speece, R.E., Parkin, G.F. 1983. The response of methane bacteria to toxicity. 3rd International Symposium on Anaerobic Digestion, Watertown, Mass. pp. 23-35.

Symons, G.E., Buswell, A.M. 1933. The Methane Fermentation of Carbohydrates1,2. Journal of the American Chemical Society, 55(5), 2028-2036.

Vogels, G.D., Keltjens, J.T., Van Der Drift, C. 1988. Biochemistry of methane production. Biology of anaerobic microorganisms, 707-770.

Walker, M., Zhang, Y., Heaven, S., Banks, C. 2009. Potential errors in the quantitative evaluation of biogas production in anaerobic digestion processes. Bioresource Technology, 100(24), 6339-6346.

Wiley, P.E., Campbell, J.E., McKuin, B. 2011. Production of biodiesel and biogas from algae: a review of process train options. Water Environment Research, 83(4), 326-338. 
Table 1 Composition of BSM

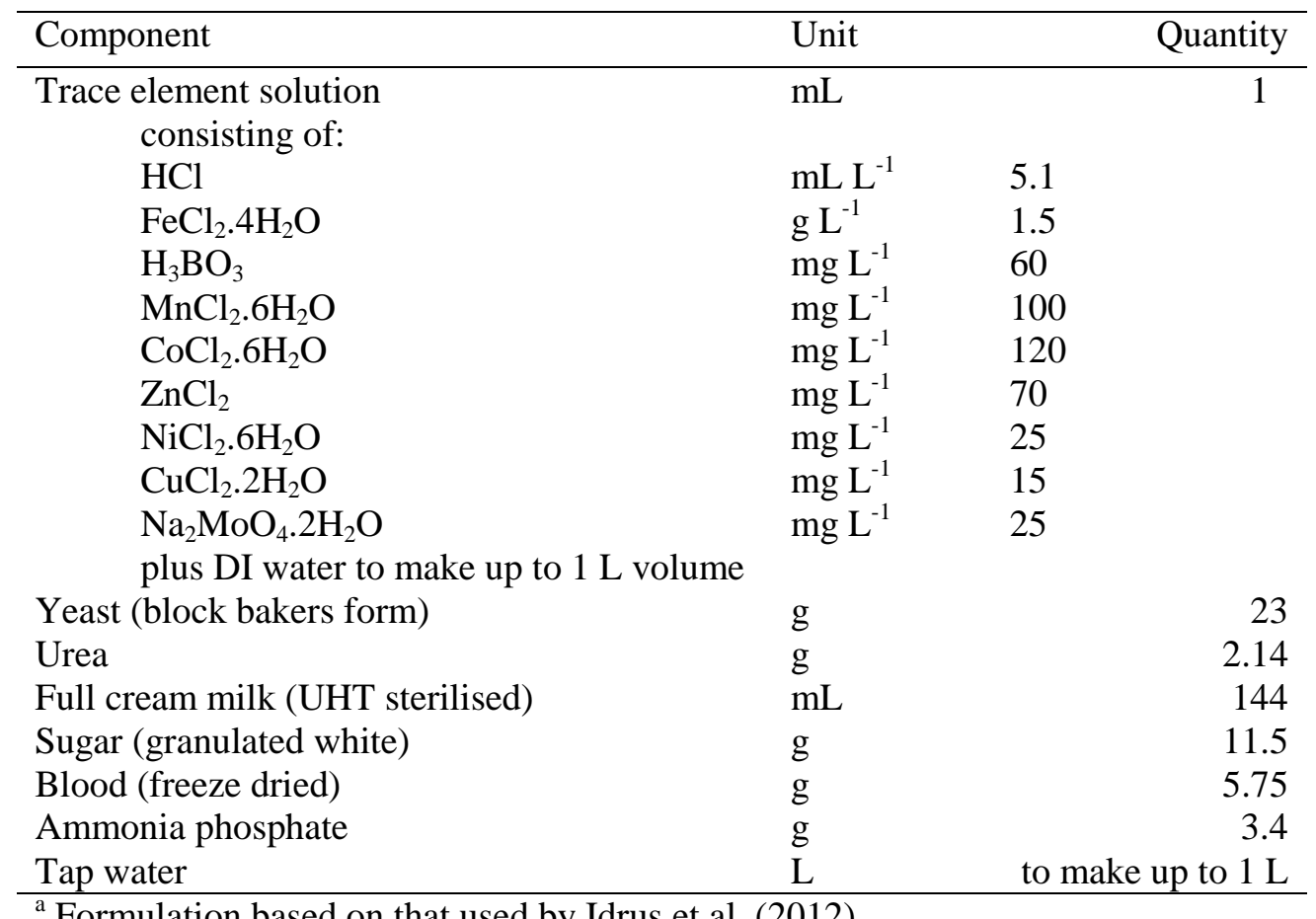


Table 2 Experimental design

\begin{tabular}{|c|c|c|c|c|c|c|c|c|c|c|}
\hline Phase & Day & Added & R1\& & & R3\&4 & \multicolumn{2}{|c|}{ R5\&6 } & R7\&8 & \multicolumn{2}{|c|}{ R9\&10 } \\
\hline 1 & $1-40$ & Salt $\mathrm{g} \mathrm{L}^{-1}$ & \multicolumn{2}{|c|}{$\begin{array}{l}8 \text { (feed } \\
\text { only) }\end{array}$} & $\begin{array}{l}16(\text { feed } \\
\text { only) }\end{array}$ & \multicolumn{2}{|c|}{$\begin{array}{l}10 \text { (spike } \\
\text { and feed })^{\text {a }}\end{array}$} & $\begin{array}{l}8 \text { (feed } \\
\text { only) }\end{array}$ & \multicolumn{2}{|c|}{0 (control) } \\
\hline 2 & $1-64$ & Salt $g^{-1}$ & \multicolumn{2}{|l|}{6} & 7 & & & 9 & \multicolumn{2}{|c|}{0 (control) } \\
\hline 3 & $65-400$ & Salt $\mathrm{g} \mathrm{L}^{-1}$ & \multicolumn{8}{|c|}{$\begin{array}{l}\text { Additional salt in salt-supplemented digesters and in feed increased } \\
\text { by } 1 \mathrm{~g} \mathrm{~L}^{-1} \text { every } 14 \text { days up to day } 350 \text {, then raised to } 31.1 \mathrm{~g} \mathrm{~L}^{-1}\end{array}$} \\
\hline \multirow{3}{*}{4} & \multirow{3}{*}{$400-580$} & & F1 & F2 & F3 & $\mathrm{F} 4$ & F5 & F6 & F7 & F8 \\
\hline & & Salt $\mathrm{g} \mathrm{L}^{-1}$ & 31.1 & 31.1 & 31.1 & 31.1 & 31.1 & 31.1 & 31.1 & 31.1 \\
\hline & & $\mathrm{SO}_{4} \mathrm{~g} \mathrm{~L}^{-1}$ & 0.00 & 0.16 & 0.79 & 1.58 & 2.36 & 3.15 & 3.94 & 4.73 \\
\hline
\end{tabular}

${ }^{\mathrm{a}}$ Laboratory salt mixture. ${ }^{\mathrm{b}}$ Commercial artificial sea salt. 
Table 3 Average properties of BSM feed

\begin{tabular}{llrll}
\hline Parameter & Unit & Value & & \\
\hline COD & $\mathrm{g} \mathrm{L}^{-1}$ & 46.1 & \pm & 1.0 \\
$\mathrm{TS}$ & $\mathrm{g} \mathrm{kg}^{-1} \mathrm{WW}$ & 32.2 & \pm & 0.40 \\
$\mathrm{VS}$ & $\% \mathrm{TS}^{-1} \mathrm{WW}$ & 90.1 & \pm & 0.01 \\
$\mathrm{TKN}$ & $\mathrm{g} \mathrm{kg}^{-1} \mathrm{WW}$ & 3.90 & \pm & 0.10 \\
Elemental & composition & & & \\
$\mathrm{C}$ & $\% \mathrm{VS}$ & 49.59 & \pm & 2.12 \\
$\mathrm{H}$ & $\% \mathrm{VS}$ & 6.20 & \pm & 0.06 \\
$\mathrm{~N}$ & $\% \mathrm{VS}$ & 6.52 & \pm & 0.22 \\
$\mathrm{~S}$ & $\% \mathrm{VS}$ & 0.31 & \pm & 0.03 \\
\hline
\end{tabular}


Table 4 Average values for key monitoring parameters in the last 20 days of Phase 2

\begin{tabular}{|c|c|c|c|c|c|c|c|c|c|c|c|}
\hline Parameter & Unit & R1 & $\mathrm{R} 2$ & R3 & $\mathrm{R} 4$ & R5 & R6 & R7 & R8 & R9 & $\overline{\mathrm{R} 10}$ \\
\hline Salt & $\mathrm{g} \mathrm{L}^{-1}$ & 6 & 6 & 7 & 7 & 8 & 8 & 9 & 9 & 0 & 0 \\
\hline $\mathrm{pH}$ & & 7.70 & 7.70 & 7.55 & 7.48 & 7.60 & 7.56 & 7.62 & 7.63 & 7.63 & 7.65 \\
\hline TAN & $\mathrm{g} \mathrm{N} \mathrm{L}^{-1}$ & 2.34 & 2.40 & 2.39 & 2.44 & 2.39 & 2.40 & 2.32 & 2.44 & 2.30 & 2.32 \\
\hline TA & $\mathrm{g} \mathrm{CaCO}_{3} \mathrm{~L}^{-1}$ & 7.49 & 7.72 & 7.27 & 7.43 & 7.25 & 7.28 & 7.19 & 7.50 & 7.63 & 7.53 \\
\hline PA & $\mathrm{g} \mathrm{CaCO}_{3} \mathrm{~L}^{-1}$ & 5.77 & 6.02 & 5.05 & 4.91 & 5.43 & 5.36 & 5.57 & 5.70 & 6.00 & 5.74 \\
\hline IA & $\mathrm{g} \mathrm{CaCO}_{3} \mathrm{~L}^{-1}$ & 1.71 & 1.70 & 2.22 & 2.52 & 1.82 & 1.92 & 1.62 & 1.80 & 1.63 & 1.79 \\
\hline IA/PA & & 0.30 & 0.28 & 0.45 & 0.54 & 0.34 & 0.36 & 0.29 & 0.32 & 0.27 & 0.31 \\
\hline TS & $\% \mathrm{WW}$ & 1.54 & 1.57 & 1.69 & 1.76 & 1.77 & 1.78 & 1.80 & 1.85 & 1.17 & 1.13 \\
\hline VS & $\% \mathrm{WW}$ & 0.80 & 0.81 & 0.84 & 0.91 & 0.86 & 0.87 & 0.82 & 0.86 & 0.85 & 0.81 \\
\hline VFA & $m g L^{-1}$ & 52 & 49 & 1591 & 2730 & 706 & 965 & 104 & 594 & 99 & 76 \\
\hline VBP & $\mathrm{LL}^{-1}$ day $^{-1}$ & 1.32 & 1.33 & 1.28 & 1.28 & 1.26 & 1.27 & 1.33 & 1.22 & 1.30 & 1.33 \\
\hline $\mathrm{CH}_{4}$ & $\%$ volume & 66.2 & 66.1 & 65.5 & 65.0 & 64.6 & 65.7 & 66.7 & 66.3 & 66.5 & 65.6 \\
\hline \multirow[t]{3}{*}{ SMP } & $\mathrm{L} \mathrm{CH}_{4} \mathrm{~g}^{-1} \mathrm{VS}$ & 0.421 & 0.422 & 0.400 & 0.395 & 0.388 & 0.396 & 0.423 & 0.384 & 0.413 & 0.420 \\
\hline & $\%$ ave control & 1.01 & 1.01 & 0.96 & 0.95 & 0.93 & 0.95 & 1.02 & 0.92 & 0.99 & 1.01 \\
\hline & $\%$ of TCV & 0.84 & 0.84 & 0.80 & 0.79 & 0.77 & 0.79 & 0.84 & 0.76 & 0.82 & 0.84 \\
\hline
\end{tabular}


Table 5 Average values for key monitoring parameters in the last 20 days of Phase 3

\begin{tabular}{|c|c|c|c|c|c|c|c|c|c|c|c|}
\hline Parameter & Unit & $\mathrm{R} 1$ & R2 & R3 & $\mathrm{R} 4$ & R5 & R6 & R7 & R8 & R9 & R10 \\
\hline Salt & $\mathrm{g} \mathrm{L}^{-1}$ & 31.1 & 31.1 & 31.1 & 31.1 & 31.1 & 31.1 & 31.1 & 31.1 & 0.0 & 0.0 \\
\hline $\mathrm{pH}$ & & 7.37 & 7.33 & 7.31 & 7.35 & 7.31 & 7.36 & 7.32 & 7.34 & 7.67 & 7.67 \\
\hline TAN & $\mathrm{g} \mathrm{N} \mathrm{L}^{-1}$ & 2.70 & 2.66 & 2.74 & 2.36 & 2.54 & 2.87 & 2.50 & 2.51 & 2.80 & 2.77 \\
\hline TA & $\mathrm{g} \mathrm{CaCO}_{3} \mathrm{~L}^{-1}$ & 7.41 & 6.76 & 6.35 & 6.43 & 6.95 & 6.72 & 6.91 & 6.89 & 8.96 & 9.14 \\
\hline PA & $\mathrm{g} \mathrm{CaCO}_{3} \mathrm{~L}^{-1}$ & 5.41 & 4.60 & 4.07 & 4.91 & 5.25 & 5.04 & 5.41 & 5.30 & 7.10 & 7.31 \\
\hline IA & $\mathrm{g} \mathrm{CaCO}_{3} \mathrm{~L}^{-1}$ & 2.01 & 2.16 & 2.28 & 1.53 & 1.70 & 1.68 & 1.50 & 1.58 & 1.86 & 1.83 \\
\hline IA/PA & & 0.37 & 0.47 & 0.59 & 0.31 & 0.32 & 0.34 & 0.28 & 0.30 & 0.27 & 0.25 \\
\hline TS & $\% \mathrm{WW}$ & 3.68 & 3.64 & 3.83 & 3.91 & 3.86 & 3.82 & 3.96 & 3.89 & 1.01 & 1.02 \\
\hline VS & $\% \mathrm{WW}$ & 0.92 & 0.89 & 0.99 & 1.01 & 0.96 & 0.95 & 0.97 & 0.96 & 0.64 & 0.70 \\
\hline VS destr & $\% \mathrm{VS}$ & 71.3 & 72.2 & 69.2 & 68.5 & 70.0 & 70.3 & 69.9 & 70.1 & 80.0 & 78.3 \\
\hline VFA & $m g L^{-1}$ & 121 & 55 & 73 & 553 & 57 & 24 & 73 & 99 & 28 & 109 \\
\hline VBP & $\mathrm{L} \mathrm{L}^{-1}$ day $^{-1}$ & 1.40 & 1.34 & 1.28 & 1.31 & 1.46 & 1.38 & 1.39 & 1.35 & 1.41 & 1.42 \\
\hline $\mathrm{CH}_{4}$ & $\%$ volume & 65.4 & 64.1 & 62.7 & 65.4 & 65.9 & 63.6 & 63.3 & 60.8 & 66.1 & 64.7 \\
\hline \multirow[t]{3}{*}{ SMP } & $\mathrm{L} \mathrm{CH}_{4} \mathrm{~g}^{-1} \mathrm{VS}$ & 0.413 & 0.390 & 0.362 & 0.386 & 0.434 & 0.398 & 0.396 & 0.372 & 0.422 & 0.416 \\
\hline & $\%$ ave c & 0.99 & 0.93 & 0.87 & 0.92 & 1.04 & 0.95 & 0.95 & 0.89 & 1.01 & 0.99 \\
\hline & $\%$ of TCV & 0.82 & 0.78 & 0.72 & 0.77 & 0.86 & 0.79 & 0.79 & 0.74 & 0.84 & 0.83 \\
\hline
\end{tabular}




\section{Figure captions}

Figure 1 SMP, VBP, $\mathrm{pH}$ and VFA in digesters during Phase 1. Vertical dotted lines indicate salt spiking and/or start of salt supplementation to feed on day 13 and cessation of feeding for R3-6 on day 35 .

Figure 2 TAN, pH, TA, total VFA, PA, IA/PA, TS, VS, VBP and 7-day average SMP during Phase 2. Vertical dotted line indicates change in salt addition (see Table 2).

Figure 3 TAN, TA, PA, IA/PA, pH, total VFA, VBP, 7-day average SMP and VFA profiles in R2 and 4 during Phases 2 and 3. Vertical dotted line $=$ change in salt addition (Table 2).

Figure 4 pH, TA, IA/PA, VFA, VBP, SMP, VS destruction and TAN during Phase 4 Figure $5 \mathrm{H}_{2} \mathrm{~S}$ ppmv, $\mathrm{H}_{2} \mathrm{~S}$ volumetric, $\mathrm{COD} / \mathrm{SO}_{4}$. 

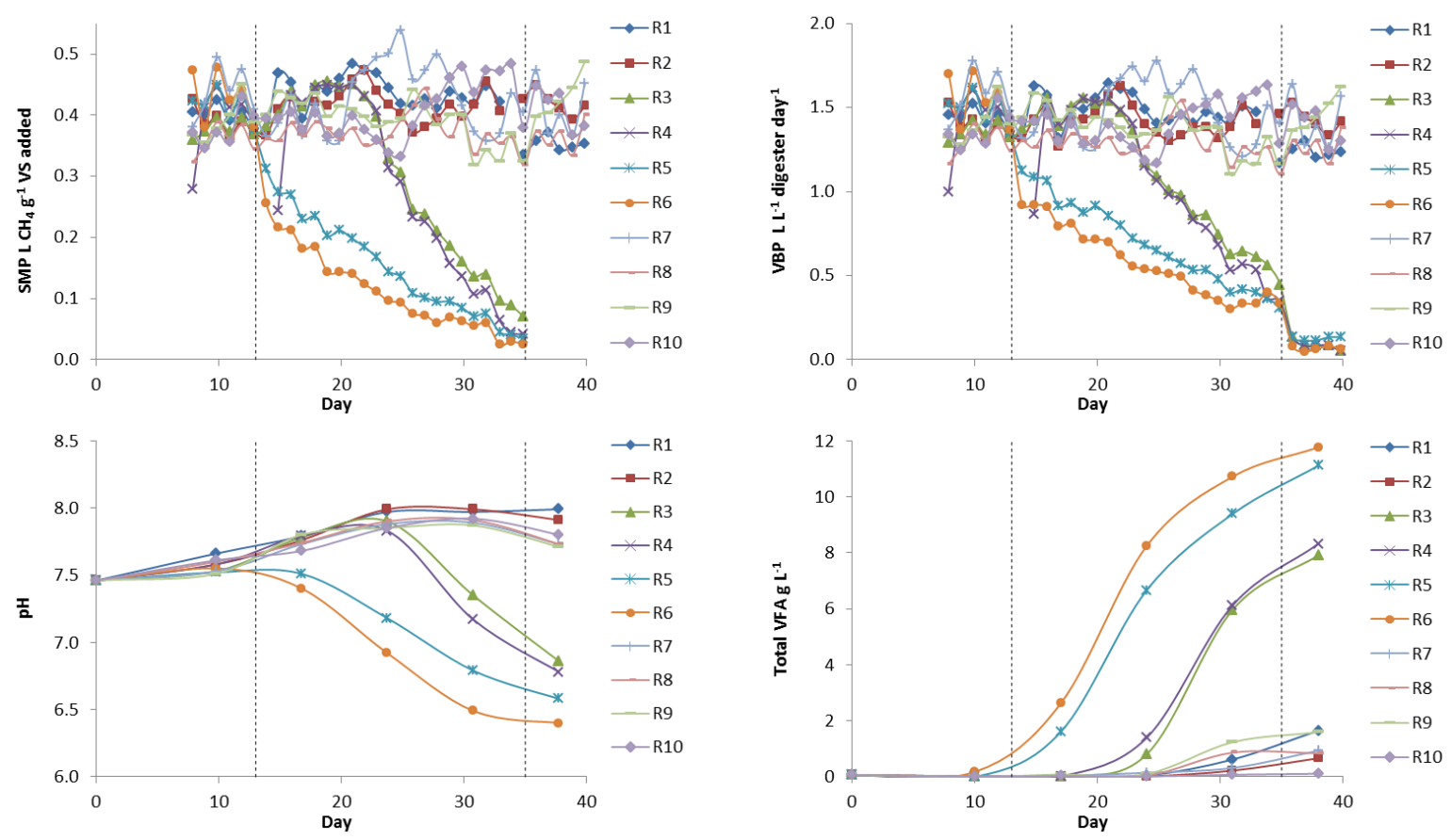

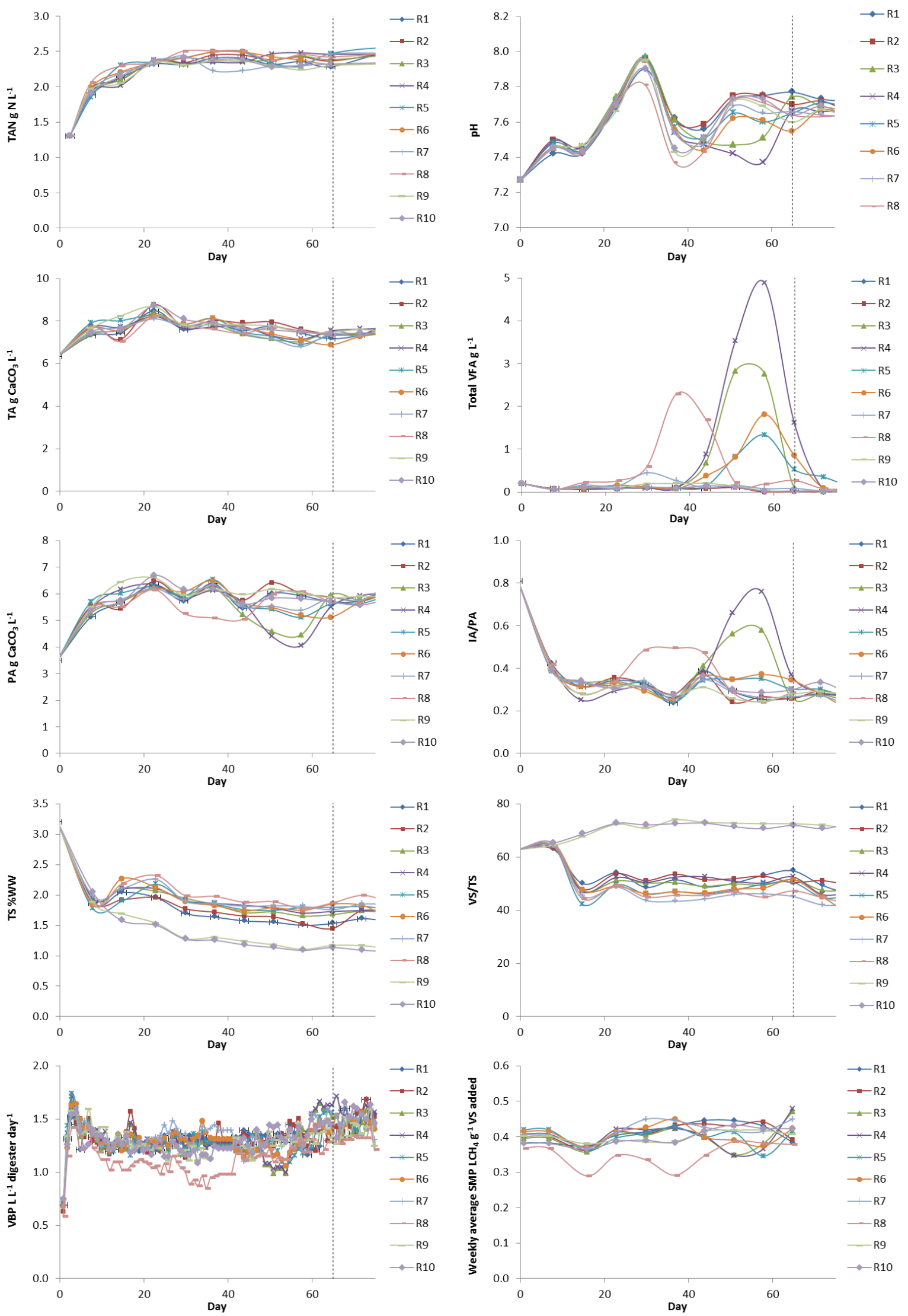

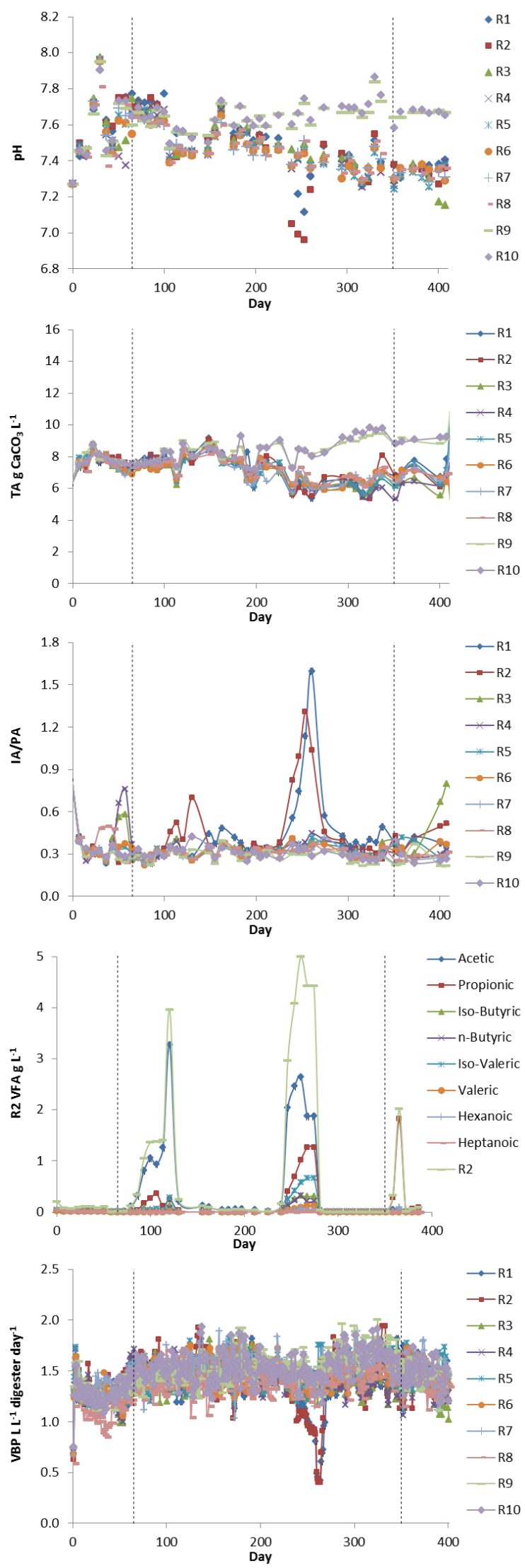
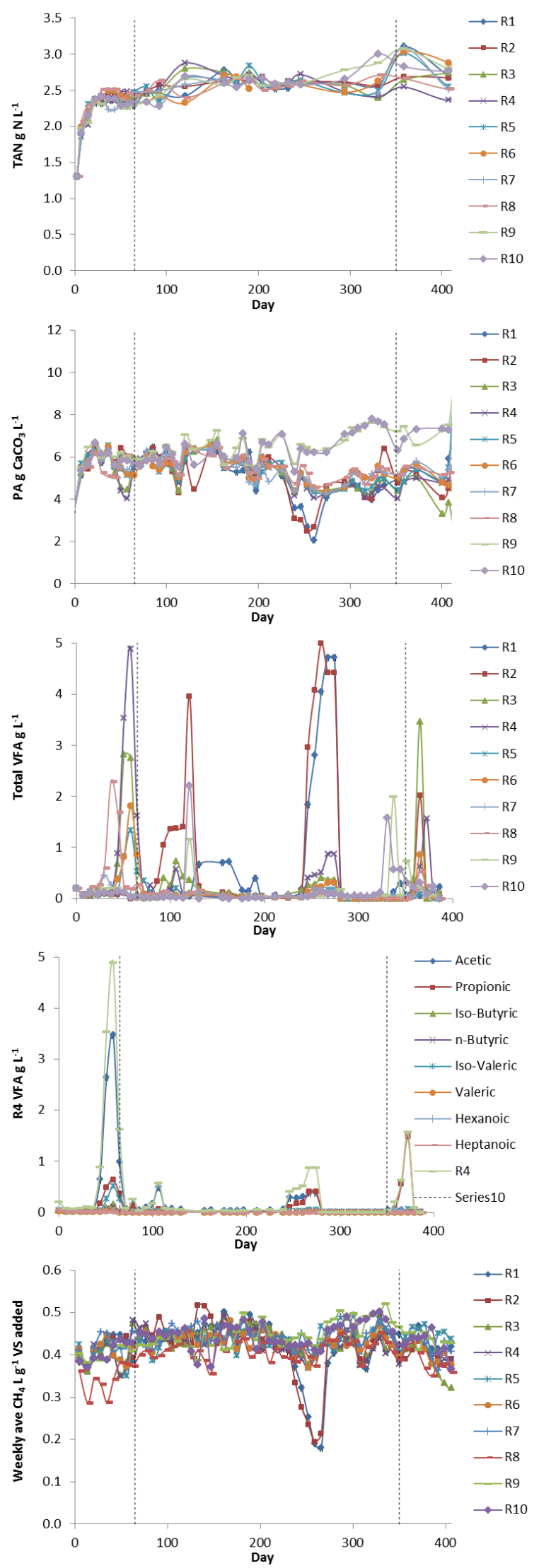

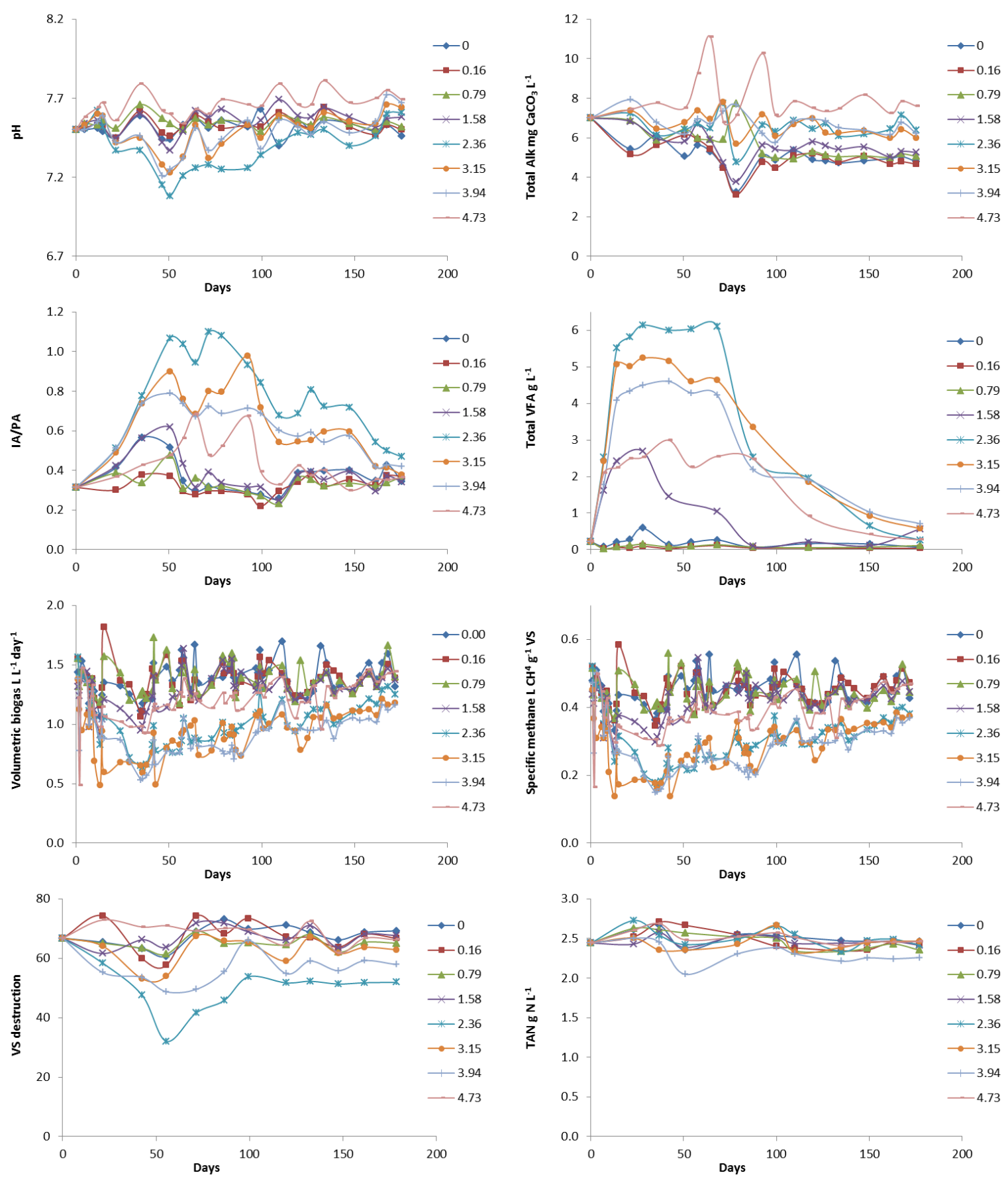

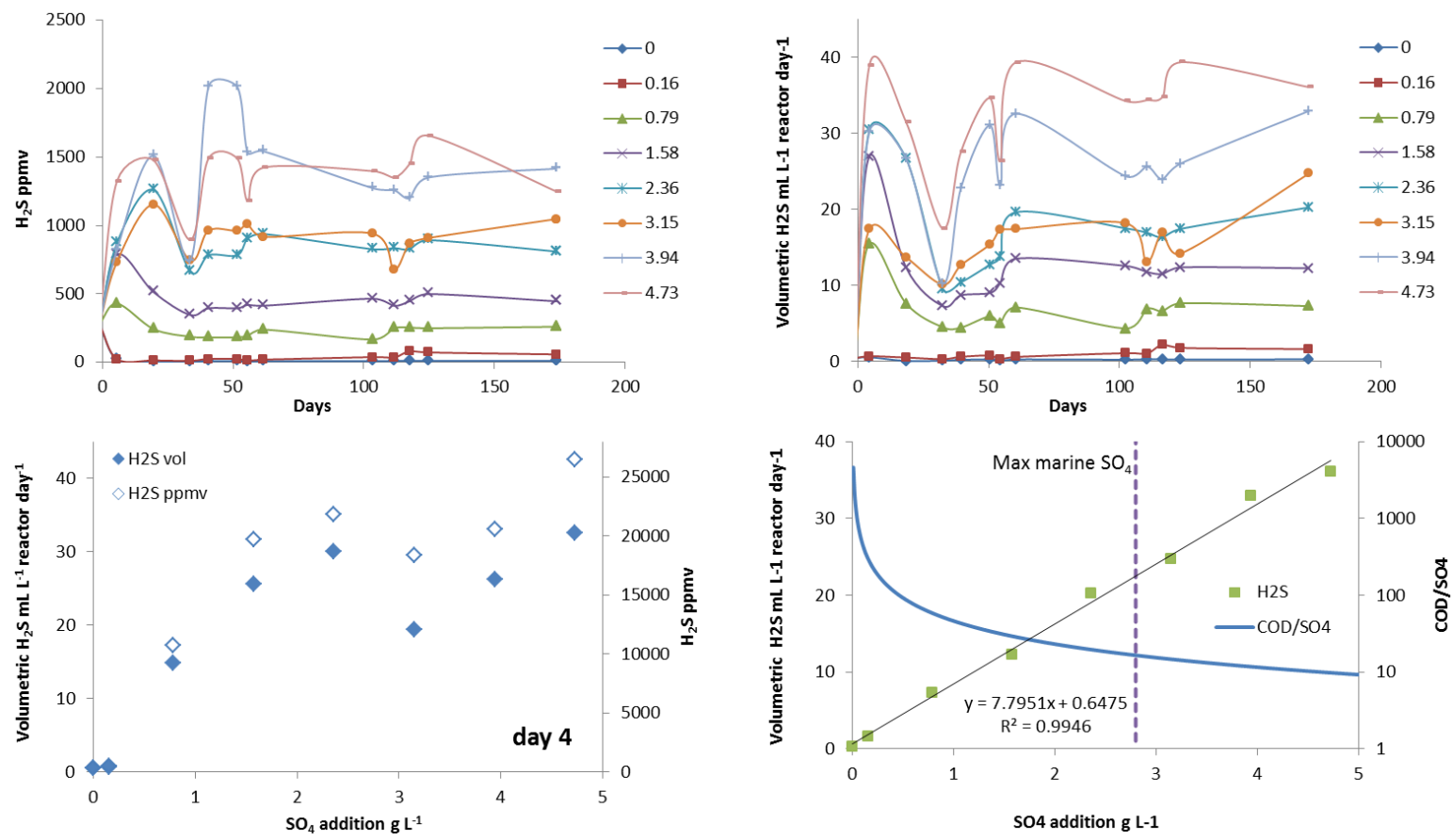

Figure $5 \mathrm{H}_{2} \mathrm{~S}$ ppmv, $\mathrm{H}_{2} \mathrm{~S}$ volumetric, $\mathrm{COD} / \mathrm{SO}_{4}$. 